\title{
Chitosan Elicitation for Enhancing of Vincristine and Vinblastine Accumulation in Cell Culture of Catharanthus roseus (L.) G. Don
}

\author{
Pawnpirun Pliankong ${ }^{1}$, Padungsak Suksa-Ard ${ }^{1} \&$ Surawit Wannakrairoj $^{2}$ \\ ${ }^{1}$ School of Agricultural Technology, Walailak University, Nakhon Si Thammarat, Thailand \\ ${ }^{2}$ Department of Horticulture, Faculty of Agriculture, Kasetsart University, Bangkok, Thailand \\ Correspondence: Pawnpirun Pliankong, School of Agricultural Technology, Walailak University, Nakhon Si \\ Thammarat, Thailand. E-mail: p.pleankong@hotmail.com
}

Received: June 22, $2018 \quad$ Accepted: September 19, $2018 \quad$ Online Published: November 15, 2018

doi:10.5539/jas.v10n12p287 URL: https://doi.org/10.5539/jas.v10n12p287

\begin{abstract}
Catharanthus roseus (L.) G. Don is an important herbal plant. There are two important alkaloids, vinblastine and vincristine, use in anti-cancer drugs. In this study production of the two alkaloids was enhanced in C. roseus cell

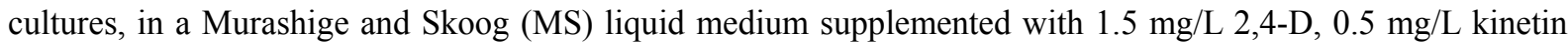
and $30 \mathrm{~g} / \mathrm{L}$ sucrose, by adding $0,50,100,250$ or $500 \mathrm{mg} / \mathrm{L}$ medium molecular weight chitosan or chitosan derived from shrimp shell. After 14 days of culture, the cell suspension at stationary phase in the $100 \mathrm{mg} / \mathrm{L}$ medium molecular weight chitosan could produce the highest amounts of vinblastine and vincristine at 4.15 and $5.48 \mu \mathrm{g} / \mathrm{mg}$ cell dry weight, respectively. At the same time, the controls ( $0 \mathrm{mg} / \mathrm{L}$ chitosan) produced the two alkaloids at only 2.43 and $2.49 \mu \mathrm{g} / \mathrm{mg}$ cell dry weight, respectively. For chitosan from shrimp shell, it was found that $100 \mathrm{mg} / \mathrm{L}$ chitosan could lead to the highest quantity of $4.09 \mu \mathrm{g}$ vinblastine/mg cell dry weight. The highest amount of $5.47 \mu \mathrm{g}$ vincristine $/ \mathrm{mg}$ cell dry weight was obtained when $250 \mathrm{mg} / \mathrm{L}$ chitosan was added.
\end{abstract}

Keywords: Catharanthus roseus, vinblastine, vincristine, chitosan

\section{Introduction}

Catharanthus roseus (L.) G. Don is commonly known as the Madagascar periwinkle (Gajalakshmi et al., 2013). It synthesized terpenoid indole alkaloids were used in medicine such as vinblastine and vincristine (Mujib et al., 2014). These alkaloids have commercially important chemotherapy drugs (Zhou et al., 2010). Normally, vinblastine and vincristine could be produced very low approximately $0.0003 \%$ of $2.56 \%$ total alkaloid content (Shukla et al., 2006), Although, C. roseus has turn into one of the best studied herbal plants, in the use of cell suspension cultures for the production of valuable secondary metabolites.

Plant cell suspension culture technologies can be established for production of secondary metabolites. In vitro production of secondary metabolites in plant cell suspensions cultures has been reported from various medicinal plants (Zhao et al., 2005). Several strategies, such as manipulating the nutrient, optimizing the culture conditions, feeding of precursor, environmental stress and elicitation, can be applied in order to substantially increase the yields of secondary metabolites in plant cell cultures (Bourgaud et al., 2001; Zhang et al., 2004). Enhancement of secondary metabolites by elicitation is one of the few strategies recently finding commercial application (Namdeo, 2007).

Elicitors are molecules that stimulate defense or stress induced responses in plants. On the basis of their nature, elicitors can be divided into 2 types such as biotic and abiotic (Sreedhar et al., 2009). Both biotic and abiotic elicitors are known to stimulate synthesis of secondary metabolite in plant cells as a result of their defensive reaction against pathogen attack (García-Brugger et al., 2006). The use of both elicitors to activate product formation has become an important develop strategy and has been very useful in reducing the process time required to achieve high product concentrations and increasing product quantity (Cai et al., 2011). Natural elicitors include polysaccharides from insect and fungal pathogen such as chitosan (Brasili et al., 2014) are frequently used in a many plant cell suspension cultures for efficient induction of pharmaceutical secondary metabolites.

Chitosan is the major component of exoskeletons of insects, crustacean and fungal cell wall (Yin et al., 2010). As a natural substance, chitosan mimics the effects of some pathogen to stimulate plant secondary metabolites 
production by producing of phytoalexins and the generating of hydrogen peroxide (Abd-Allah \& Hashem, 2006). Chitosan has been confirmed as an effective biotic elicitor for improving biosynthesis of secondary metabolites in cell cultures of several medicinal species. The main aim of this study was to examine the effects of chitosan elicitation in the $C$. roseus cell suspension culture, accumulation of vinblastine and vincristine. Moreover, to find the feasible relations between plant chitosan concentrations and vinblastine and vincristine accumulations under chitosan elicitation.

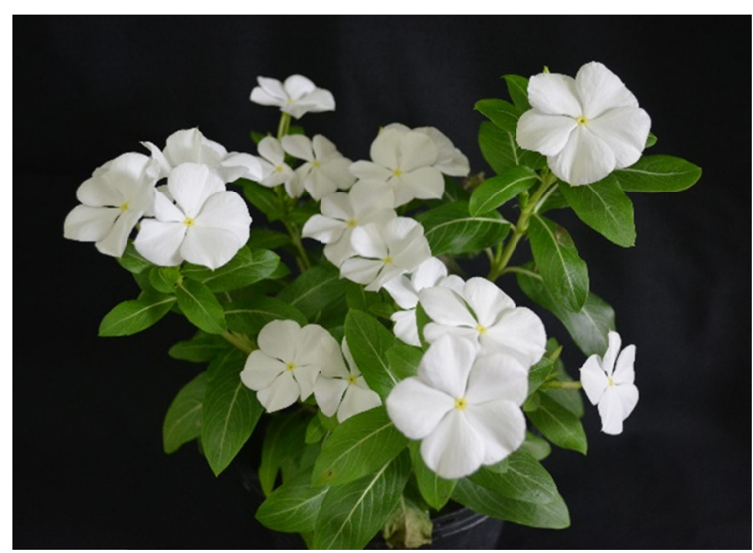

Figure 1. Catharanthus roseus (L.) G. Don

\section{Method}

\subsection{Plant Materials and Explants Preparation}

A cultivar of C. roseus with white flower was used as plant material (Figure 1). The healthy shoot tips, $1 \mathrm{~cm}$ in length, were soaked in $70 \%(\mathrm{v} / \mathrm{v})$ ethanol for $10 \mathrm{sec}$, followed by sterilization in $1 \%(\mathrm{v} / \mathrm{v})$ sodium hypochlorite for $15 \mathrm{~min}$, with 2 drops of Tween-20. The samples then washed with sterile distilled water 3 times.

\subsection{Callus Induction}

The shoot tips were cultured in MS liquid medium supplement with $1.5 \mathrm{mg} / \mathrm{L} \mathrm{2,} \mathrm{4-D} \mathrm{and} 30 \mathrm{~g} / \mathrm{L}$ sucrose, $\mathrm{pH} 5.8$. They were cultured in the dark at $25 \pm 2{ }^{\circ} \mathrm{C}$ on orbital shaker at $100 \mathrm{rpm}$ and subcultured every 3 weeks.

\subsection{Cell Suspension Culture Preparation}

Cell suspension culture was done by transferring $1 \mathrm{~g}$ fresh weight friable callus, 12 weeks old after subculture, to

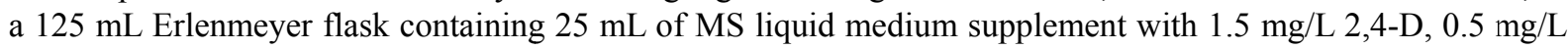
kinetin and $30 \mathrm{~g} / \mathrm{L}$ sucrose, $\mathrm{pH}$ 5.8. The suspension cultures were placed on orbital shaker at $100 \mathrm{rpm}$ and cultured at $25 \pm 2{ }^{\circ} \mathrm{C}$ under 16 -h photoperiods with a light fluorescent lamp intensity of $36 \mu \mathrm{mol} / \mathrm{m}^{2} / \mathrm{s}$. Due to continuous agitation, the friable callus was broken and dispensed releasing cell clump and cells in the medium. Finally the single cells were filtrated by using nylon mesh $(120 \mu \mathrm{m})$. After that the filtrate contained cell suspension was cultured in MS liquid medium supplemented with $1.5 \mathrm{mg} / \mathrm{L} \mathrm{2,4-D,} 0.5 \mathrm{mg} / \mathrm{L}$ kinetin and $30 \mathrm{~g} / \mathrm{L}$ sucrose, pH 5.8 and subcultured every 14 days for inoculum cell.

\subsection{Cell Suspension Growth Measurement}

Measurement of growth of cell culture was performed by culturing $5 \mathrm{~mL}$ cell suspension in $125 \mathrm{~mL}$ Erlenmeyer flask with $20 \mathrm{~mL}$ of MS liquid medium supplement with $1.5 \mathrm{mg} / \mathrm{L}$ 2,4-D, $0.5 \mathrm{mg} / \mathrm{L}$ kinetin and $30 \mathrm{~g} / \mathrm{L}$ sucrose, $\mathrm{pH}$ 5.8. The cell cultures were cultured at $25 \pm 2{ }^{\circ} \mathrm{C}$ under 16 -h photoperiods with a light fluorescent lamp intensity of $36 \mu \mathrm{mol} / \mathrm{m}^{2} / \mathrm{s}$ and shaked at $100 \mathrm{rpm}$ on orbital shaker. Every day, $100 \mu \mathrm{l}$ of cell suspension were taken out for cell counting on haemacytometer under light microscope. Growth curve was plotted as shown in Figure 2. 


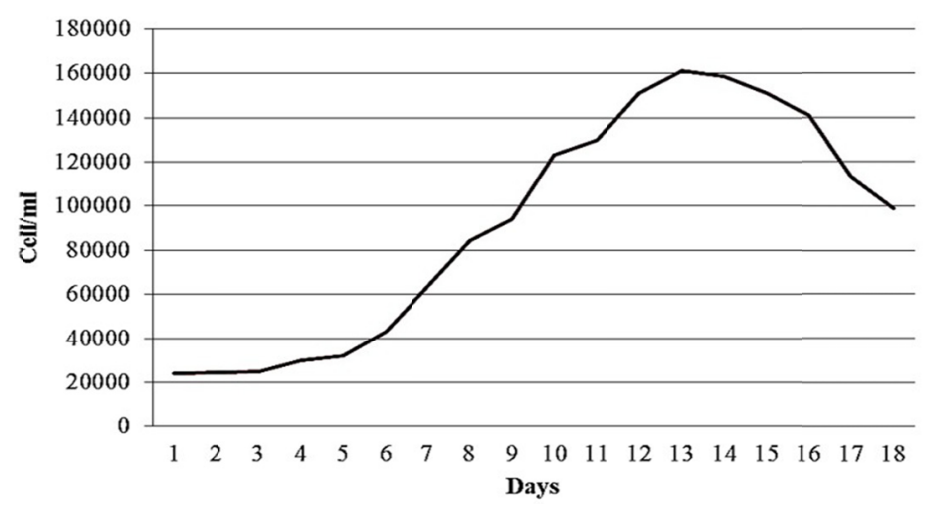

Figure 2. Growth curve of C. roseus cell suspension culture

\subsection{Elicitor Preparation}

In the present study, two chitosans (medium molecular weight and from shrimp shell; Sigma-Alrich Co., Ltd.) were dissolved in $0.1 \mathrm{M}$ acetic acid by gentle heating at $60{ }^{\circ} \mathrm{C}$ and continuous stirring until dissolved. The $\mathrm{pH}$ of the solution was adjusted to 5.8 with $1 \mathrm{M} \mathrm{NaOH}$.

\subsection{Elicitation Treatment}

The cell suspension, 14 days old, were cultured in $125 \mathrm{~mL}$ Erlenmeyer flask with $20 \mathrm{~mL}$ of MS liquid medium supplement with $1.5 \mathrm{mg} / \mathrm{L}$ 2,4-D, $0.5 \mathrm{mg} / \mathrm{L}$ kinetin and $30 \mathrm{~g} / \mathrm{L}$ sucrose, $\mathrm{pH}$ 5.8. The media were added with medium molecular weight or shrimp shell chitosan at the same concentration of $0,50,100,250$ and $500 \mathrm{mg} / \mathrm{L}$. Each experiment has three replicates. The suspension cultures were placed on orbital shaker at $100 \mathrm{rpm}$ and $25 \pm 2{ }^{\circ} \mathrm{C}$ under 16 -h photoperiods with light fluorescent lamp intensity of $36 \mu \mathrm{mol} / \mathrm{m}^{2} / \mathrm{s}$.

\subsection{Vinblastine and Vincristine Analysis by HPLC}

The cell biomass of the suspension culture was harvested at 14 days after culture initiation by filtrated through $42 \mu \mathrm{m}$ nylon mesh and freezing dried. Approximately $200 \mathrm{mg}$ of dry cells wasextracted at room temperature in 1 $\mathrm{mL}$ of $95 \%$ methanol for $60 \mathrm{~min}$ in a sonicating bath. The extract was centrifuged at $15,000 \mathrm{~g}$ for $5 \mathrm{~min}$ then the supernatant was filtered through a $0.45 \mu \mathrm{m}$ Millipore-filter into an amber glass HPLC vial prior to HPLC analysis.

Individual stock solutions of vincristine (vincristine sulfate, CALBIOCHEM) and vinblastine (vinblasine sulfate, CALBIOCHEM) were prepared at a concentration of $5 \mathrm{mg} / \mathrm{mL}$ in $95 \%$ methanol. These stock solutions were stored at $0{ }^{\circ} \mathrm{C}$. The analysis was performed by using a Waters (Milford, MA, USA) HPLC system comprising a Waters 2690 programmable photodiode array detector, Waters 717 autosampler and Waters 600 pump. The separations were carried out using a Lichrocart@250-4 column $(150 \times 4.6 \mathrm{~mm}, 5 \mu \mathrm{m}$ particle size $)$. The mobile phase consisted of a gradient mixture of $0.02 \mathrm{mM} \mathrm{Na} \mathrm{HPO}_{4}$ [pH adjusted to 6 with $\mathrm{H}_{3} \mathrm{PO}_{4}$ (solvent $\mathrm{A}$ ) and $95 \%$ methanol (solvent B)]. Flow rate was $2.0 \mathrm{~mL} / \mathrm{min}$. The eluent profile (volume of solvent A/volume of solvent B) was $20 \mathrm{~min}$, linear gradient from 80:20 to 20:80; $20 \mathrm{~min}$, isocratic elution with 20:80 (v/v) for column rinsing and $25 \mathrm{~min}$, isocratic elution with 80:20 (v/v) for column equilibration (Tikhomiroff and Jolicoeur, 2002). The retention times of vinblastine and vincristine chromatogram from standard and samples were 3.086 and 3.534 minutes (Figure 3 ). 

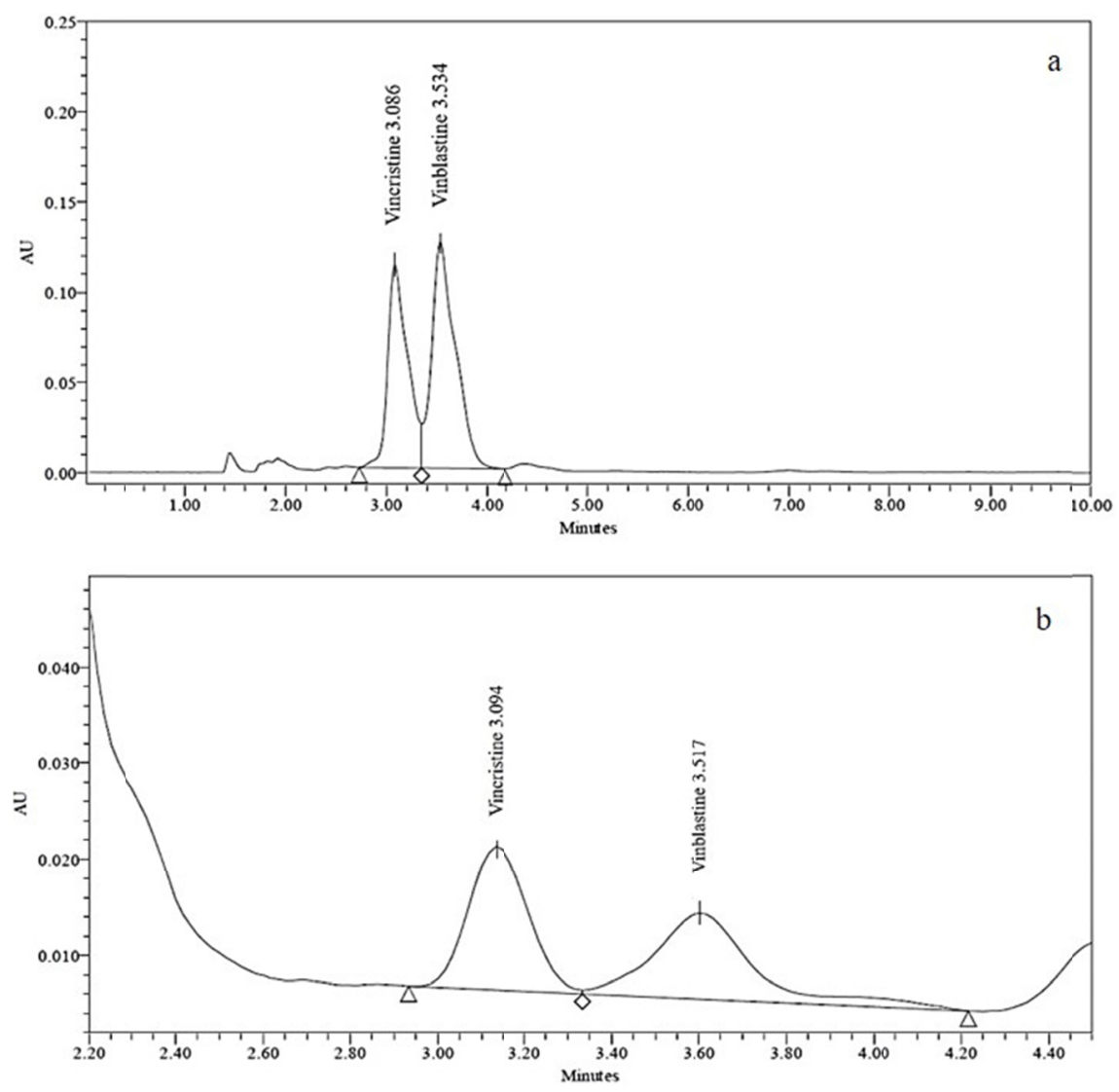

Figure 3. HPLC chromatogram showing standard vincristine and vinblastine (a) with the chromatogram showing the presence of vincristine and vinblastine (b) in cell culture extract of C. roseus

\subsection{Data Analysis}

All data collected from the experiments were analyzed using analysis of variance (ANOVA) with R program. Significant differences between mean assessed by LSD at $\mathrm{P} \leq 0.01$.

\section{Results}

\subsection{Accumulation of Vinblastine and Vincristine in Cell Culture}

Accumulation of vinblastine and vincristine in growth phase of cell suspension showed that the accumulation of vinblastine and vincristine increased with the growth phase of the cell. The lag phase, 3 days after culture cell accumulated vinblastine and vincristine at 1.74 and $1.83 \mu \mathrm{g} / \mathrm{mg}$ cell dry weight. In the exponential phase 7 day after culture, the cell accumulations of vinblastine and vincristine were 2.11 and $2.27 \mu \mathrm{g} / \mathrm{mg}$ cell dry weight. In the stationary phase 12 day after cultured, the cell accumulations of vinblastine and vincristine were obtained at 2.61 and $2.52 \mu \mathrm{g} / \mathrm{mg}$ cell dry weight respectively (Table 1 ).

Table 1. Accumulation of vinblastine and vincristine in C. roseus cell suspension culture, without stimulant, in lag phase ( 3 days after culture), exponential phase ( 7 days after culture) and stationary phase (12 days after culture)

\begin{tabular}{lll}
\hline Growth phase & Vinblastine $^{1}(\mu \mathrm{g} / \mathrm{mg}$ cell dry weight $)$ & Vincristine $^{1}(\mu \mathrm{g} / \mathrm{mg}$ cell dry weight $)$ \\
\hline Lag phase & $1.74 \pm 0.17^{\mathrm{c}}$ & $1.83 \pm 0.16^{\mathrm{c}}$ \\
Exponential phase & $2.11 \pm 0.19^{\mathrm{b}}$ & $2.27 \pm 0.22^{\mathrm{b}}$ \\
Stationary phase & $2.61 \pm 0.21^{\mathrm{a}}$ & $2.52 \pm 0.24^{\mathrm{a}}$ \\
\hline F-test & $* *$ & 5.89 \\
C.V. $(\%)$ & 6.73 & 5.89 \\
\hline
\end{tabular}

Note. ${ }^{1}$ Data represented mean \pm S.D. The different letters within the same column showed significant differences at $\mathrm{P} \leq 0.01$ analyzed by LSD. ${ }^{* *}=$ significant difference at $\mathrm{P} \leq 0.01$. 


\subsection{Effect of Chitosan Elicitors on Vinblastine and Vincristine Accumulation}

The accumulation of vinblastine and vincristine from suspension cells were found to be stimulated by using two types of chitosan as elicitor stimulants. For medium molecular weight chitosan, it was found that the concentration of $100 \mathrm{mg} / \mathrm{L}$ was the most effective concentration, enhancing vinblastine and vincristine accumulation at 4.15 and $5.48 \mu \mathrm{g} / \mathrm{mg}$ cell dry weight respectively., The molecular weights of 250,500 and 50 $\mathrm{mg} / \mathrm{L}$ were found to produce vinblastine at 3.8,5 2.96 and $2.68 \mu \mathrm{g} / \mathrm{mg}$ cell dry weight, respectively, and produce vincristine at 5.20, 3.91 and 3.66 respectively., The controls produced vinblastine and vincristine only 2.43 and $2.49 \mu \mathrm{g} / \mathrm{mg}$ cell dry weight, respectively (Table 2).

For chitosan from shrimp shell, the most effective concentration for vinblastine induction was $100 \mathrm{mg} / \mathrm{L}$. It led to the yield of vinblastine at $4.09 \mu \mathrm{g} / \mathrm{mg}$ cell dry weight. For vincristine induction, the most effective concentration was $250 \mathrm{mg} / \mathrm{L}$. It could produce the highest amount of $5.47 \mu \mathrm{g}$ vincristine $/ \mathrm{mg}$ cell dry weight (Table 3 ). When comparing of both chitosan efficiencies on enhancing vinblastine and vincristine accumulation in cell suspension, it was found that there was no difference in the accumulation of vinblastine and vincristine.

Table 2. Vinblastine and vincristine accumulation in C. roseus cell suspension culture with medium molecular weight chitosan (12 days after culture)

\begin{tabular}{lll}
\hline Chitosan $(\mathrm{mg} / \mathrm{L})$ & Vinblastine $^{1}(\mu \mathrm{g} / \mathrm{mg}$ cell dry weight $)$ & Vincristine $^{1}(\mu \mathrm{g} / \mathrm{mg}$ cell dry weight $)$ \\
\hline 0 & $2.43 \pm 0.23^{\mathrm{e}}$ & $2.49 \pm 0.22^{\mathrm{e}}$ \\
50 & $2.68 \pm 0.24^{\mathrm{d}}$ & $3.66 \pm 0.38^{\mathrm{d}}$ \\
100 & $4.15 \pm 0.39^{\mathrm{a}}$ & $5.48 \pm 0.51^{\mathrm{a}}$ \\
250 & $3.85 \pm 0.36^{\mathrm{b}}$ & $5.20 \pm 0.49^{\mathrm{b}}$ \\
500 & $2.96 \pm 0.27^{\mathrm{c}}$ & $3.91 \pm 0.32^{\mathrm{c}}$ \\
\hline F-test & $* *$ & $* *$ \\
C.V. $(\%)$ & 6.73 & 5.89 \\
\hline
\end{tabular}

Note. ${ }^{1}$ Data represented mean \pm S.D. The different letters within the same column showed significant differences at $\mathrm{P} \leq 0.01$ analyzed by LSD. ${ }^{* *}=$ significant difference at $\mathrm{P} \leq 0.01$.

Table 3. Vinblastine and vincristine accumulation in C. roseus cell suspension culture with chitosan from shrimp shell (12 days after culture)

\begin{tabular}{lll}
\hline Chitosan $(\mathrm{mg} / \mathrm{L})$ & Vinblastine $^{1}(\mu \mathrm{g} / \mathrm{mg}$ cell dry weight) & Vincristine $^{\mathrm{l}}(\mu \mathrm{g} / \mathrm{mg}$ cell dry weight $)$ \\
\hline 0 & $2.54 \pm 0.23^{\mathrm{e}}$ & $2.48 \pm 0.22^{\mathrm{d}}$ \\
50 & $2.58 \pm 0.25^{\mathrm{d}}$ & $2.50 \pm 0.24^{\mathrm{d}}$ \\
100 & $4.09 \pm 0.41^{\mathrm{a}}$ & $4.28 \pm 0.38^{\mathrm{b}}$ \\
250 & $3.23 \pm 0.31^{\mathrm{b}}$ & $5.47 \pm 0.52^{\mathrm{a}}$ \\
500 & $3.13 \pm 0.29^{\mathrm{c}}$ & $2.97 \pm 0.25^{\mathrm{c}}$ \\
\hline F-test & $* *$ & $* *$ \\
C.V. (\%) & 5.66 & 6.53 \\
\hline
\end{tabular}

Note. ${ }^{1}$ Data represented mean \pm S.D. The different letters within the same column showed significant differences at $\mathrm{P} \leq 0.01$ analyzed by LSD. $* *=$ significant difference at $\mathrm{P} \leq 0.01$

\section{Discussion}

The present study was carried out to investigate the effect of chitosan on vincristine and vinblastine in cell suspension in C. roseus. We could enhance products of vincristine and vinblastine in response to chitosan elicitation. In this study, we found the distinction in the accummulation of vinblastine and vincristine during different development phases. It was found that both alkaloid were highly accumulated in the stationary phase because the substances were accumulated in vacuole and stationary phase had a large of vacuole than the other phase (Roytrakul \& Verpoorte, 2007).

For the chitosan as a stimulant, chitosan is known to elicit activities leading to a variety of defensive responses in host plants to microbial infections, including the accumulation of phytoalexins, pathogen related proteins, callus formation and accumulation of secondary metabolite (Yin et al., 2012). This study found that the most effectivechitosan concentrations for inducing vinblastine and vincristine in C. roseus cell culture were 100 to 250 
$\mathrm{mg} / \mathrm{L}$ because itinduced programmed cell death and hypersensitive-associated responses in plants cell when concentration increased (Vasil'ev et al., 2009) or chitosan toxicity to the living cells or might be due to the phytotoxic action of vinblastine and vincristine on the cells (Amborabé et al., 2008). These results also agreed with the studies in Plumbago indica root cultures of Jaisi and Panichayupakaranant (2016). They found that treatment with chitosan at concentrations of $150 \mathrm{mg} / \mathrm{L}$ to 14 days old culture increased the production of plumbagin (13.08 mg/g dry weight) by up to 6.6-fold compared to the level of an untreated root culture (1.97 $\mathrm{mg} / \mathrm{g}$ dry weight). The cell culture of Withania somnifera of Sivanandhan et al. (2012) reported that chitosan at $100 \mathrm{mg} / \mathrm{L}$ stimulated higher production of all withanolides about $323.85 \mathrm{mg} / \mathrm{g}$ dry weight when compared to control (19.05 mg/g dry weight). Ahmed and Baig (2014) showed that chitosan elicitors at $125 \mathrm{mg} / \mathrm{L}$ lead to 8 -fold (7,982 $\mu \mathrm{g} / \mathrm{g}$ dry weight) higher psoralen accumulation in Psoralea corylifolia $\mathrm{L}$. cell culture over control cells $(945 \mu \mathrm{g} / \mathrm{g}$ dry weight).

\section{Conclusion}

This is the first report of the effects of chitosan on vincristine and vinblastine yields in cell suspension cultures of C. roseus. The observation suggests that chitosan efficiently enhances vincristine and vinblastine yields especially when stimulated with $100 \mathrm{mg} / \mathrm{L}$ chitosan medium molecular weight. The identification of sign of chitosan in biosynthesis could be a very effective reach for large-scale development of both alkaloid yields for pharmaceutical industry.

\section{Acknowledgements}

We are grateful for the financial support of Walailak University graduate funding (Grant NO. WU58115 and WU59125).

\section{References}

Abd-Allah, E. E., \& Hashem, A. (2006). Seed mycoflora of Lens esculenta and their biocontrol by chitosan. Phytoparasitica, 34(2), 213-218. https://doi.org/10.1007/BF02981322

Ahmed, S. A., \& Baig, M. M. V. (2014). Biotic elicitor enhanced production of psoralen in suspension cultures of Psoralea corylifolia L. Saudi Journal of Biological Sciences, 21, 499-504. https://doi.org/10.1016/j.sjbs. 2013.12.008

Amborabé, B. E., Bonmort, J., Fleurat-Lessard, P., \& Roblin, G. (2008). Early events induced by chitosan on plant cells. Journal of Experimental Botany, 59, 2317-2324. https://doi.org/10.1093/jxb/ern096

Brasili, E., Praticò, G., Marini, F., Valletta, A., Capuani, G., Sciubba, F., Miccheli, A., \& Pasqua, G. (2014). A non-targeted metabolomics approach to evaluate the effects of biomass growth and chitosan elicitationon primary and secondary metabolism of Hypericum perforatum in vitro roots. Metabolomics, 10, 1186-1196. https://doi.org/10.1007/s11306-014-0660-z

Bourgaud, F., Gravot, A., Milesi, S., \& Gontier, E. (2001). Production of plant secondary metabolites: A historical perspective. Plant Science, 161, 839-851. https://doi.org/10.1016/S0168-9452(01)00490-3

Cai, Z., Kastell, A., Mewis, I., Knorr, D., \& Smetanska, I. (2011). Polysaccharide elicitors enhance anthocyanin and phenolic acid accumulation in cell suspension cultures of Vitis vinifera. Plant Cell, Tissue and Organ Culture, 3, 401-409.

Gajalakshmi, S., Vijayalakshmi, S., \& Devi, R. V. (2013). Pharmacological activities of Catharanthus roseus: A perspective review. International Journal of Pharma and Bio Sciences, 4(2), 431-439.

García-Brugger, A., Lamotte, O., Vandelle, E., Bourque, S., Lecourieux, D., Poinssot, B., ... Pugin, A. (2006). Early signaling events induced by elicitors of plant defenses. Molecular Plant Microbe Interactions, 19, 711-724. https://doi.org/10.1094/MPMI-19-0711

Jaisi, A., \& Panichayupakaranant, P. (2016). Increased production of plumbagin in Plumbago indica root cultures by biotic and abiotic elicitors. Biotechnology Letters, 38, 351-355. https://doi.org/10.1007/s10529 $-015-1969-\mathrm{z}$

Kevin, L. Y. W., Hussin, A. H., Zhari, I., \& Chin, J. H. (2012). Sub-acute oral toxicity study of methanol leaves extract of Catharanthus roseus in rats. Journal of Acute Disease, 1(1), 38-41. https://doi.org/10.1016/ S2221-6189(13)60009-8

Mujib, A., Ali, M., \& Isah, T. (2014). Somatic embryo mediated mass production of Catharanthus roseus in culture vessel (bioreactor) -A comparative study. Saudi Journal of Biological Sciences, 21, 442-449. https://doi.org/10.1016/j.sjbs.2014.05.007 
Namdeo A. G. (2007). Plant cell elicitation for production of secondary metabolites: A Review. Pharmacognosy Reviews, 1, 69-79.

Roytrakul, S., \& Verpoorte, R. (2007). Role of vacuolar transporter proteins in plant secondary metabolism: Catharanthus roseus cell culture. Phytochemistry Reviews, 6,383-396. https://doi.org/10.1007/s11101-0069022-4

Shukla, A. K., Shasany, A. K., Gupta, M. M., \& Khanuja, P. S., (2006). Transcriptome analysis in Catharanthus roseus leaves and roots comparative terpenoid indole alkaloid profiles. Journal of Experimental Botany, 57, 3921-3932. https://doi.org/10.1093/jxb/erl146

Sivanandhana, G., Aruna, M., Mayavana, S., Rajesha, M., Mariashibub, T. S., Manickavasagama, M., Selvarajc, N., \& Ganapathia, A. (2012). Chitosan enhances withanolides production in adventitious root cultures of Withania somnifera (L.) Dunal. Industrial Crops and Products, 37, 124-129. https://doi.org/10.1016/ j.indcrop.2011.11.022

Sreedhar, R. V., Roohie, K., Maya, P., Venkatachalam, L., \& Bhagyalakshmi, N. (2009). Biotic elicitors enhance flavour compounds during accelerated curing of vanilla beans. Food Chemistry, 112, 461-468. https://doi.org/10.1016/j.foodchem.2008.05.108

Tikhomiroff, C., \& Jolicoeur, M. (2002). Screening of Catharanthus roseus secondary metabolites by high-performance liquid chromatography. Journal of Chromatography A, 955, 87-93. https://doi.org/ 10.1016/S0021-9673(02)00204-2

Vasil'ev, L. A., Dzyubinskaya, E. V., Zinovkin, R. A., Kiselevsky, D. B., Lobysheva, N. V., \& Samuilov, V. D. (2009). Chitosan-induced programmed cell death in plants. Biochem Moscow, 74, 1035-1043. https://doi.org/10.1134/S0006297909090120

Yin, H., Zhao, X. M., \& Du Y. G. (2010). Oligochitosan a plant diseases vaccine-A review. Carbohydrat Polymers, 82, 1-8. https://doi.org/10.1016/j.carbpol.2010.03.066

Yin, H., Kjaer, A., Frett, X. C., Du, Y., Christensen, L. P., Jensena, M., \& Grevsen, K. (2012). Chitosan oligosaccharide and salicylic acid up-regulate gene expression differently in relation to the biosynthesis of artemisinin in Artemisia annua L. Process Biochemistry, 47, 1559-1562. https://doi.org/10.1016/j.procbio. 2011.12.020

Zhang, C., Yan, Q., Cheuk, W., \& Wu, J. (2004). Enhancement of tanshinone production in Salvia miltiorrhiza hairy root culture by $\mathrm{Ag}^{+}$elicitation and nutrient feeding. Planta Medica, 70, 147-151. https://doi.org/ $10.1055 / \mathrm{s}-2004-815492$

Zhao, J., Lawrence, T., Davis, C., \& Verpoorte, R. (2005). Elicitor signal transduction leading to production of plant secondary metabolites. Biotechnology Advances, 23, 283-333. https://doi.org/10.1016/j.biotechadv. 2005.01 .003

Zhou, M. L., Hou, H. L., Zhu, X. M., Shao, J. R., Wu, Y. M., \& Tang, Y. X., (2010). Molecular regulationof terpenoid indole alkaloids pathway in themedicinal plant, Catharanthus roseus. Journal of Medicinal Plant Research, 4, 663-673.

\section{Copyrights}

Copyright for this article is retained by the author(s), with first publication rights granted to the journal.

This is an open-access article distributed under the terms and conditions of the Creative Commons Attribution license (http://creativecommons.org/Licenses/by/4.0/). 